\title{
Post-nesting migratory movements of hawksbill turtles Eretmochelys imbricata in waters adjacent to the Yucatan Peninsula, Mexico
}

\author{
Eduardo Cuevas ${ }^{1, *}$, F. Alberto Abreu-Grobois ${ }^{2}$, Vicente Guzmán-Hernández ${ }^{3}$, \\ M. A. Liceaga-Correa ${ }^{1}$, Robert P. van Dam ${ }^{4}$ \\ ${ }^{1}$ CINVESTAV-IPN, Km. 6 Antig Carr. Progreso, A. P. 73 Cordemex, C. P. 97310, Mérida, Yucatán, México \\ ${ }^{2}$ Unidad Académica Mazatlán, Instituto de Ciencias del Mar y Limnología, UNAM. Calz. Joel Montes Camarena s/n, \\ C.P. 82320, Mazatlán, Sinaloa, México \\ ${ }^{3}$ Área de Protección de Flora y Fauna Laguna de Términos, Comisión Nacional de Áreas Naturales Protegidas, \\ Av. Adolfo López Mateos, Prolongación Playa Norte, C. P. 24140, Ciudad del Carmen, Campeche, México \\ ${ }^{4}$ Chelonia Inc., PO Box 902708, San Juan, Puerto Rico 00902-0708, USA
}

\begin{abstract}
The Yucatan Peninsula harbors the largest nesting population of hawksbill turtle Eretmochelys imbricata in the Atlantic Basin. In Mexico, one of the most significant conservation problems for this species is the lack of knowledge on migratory patterns and the location of feeding grounds for post-nesting hawksbill females. The main goal of this study was to gather information on the hawksbill's migratory patterns and the location of their feeding grounds by tracking 3 post-nesting females from Campeche state, Mexico. We attached satellite transmitters and tracked the 3 turtles for 166, 446 and $510 \mathrm{~d}$, respectively. The turtles remained within Mexican territorial waters, reaching separate foraging grounds off the coast of Campeche and in the Mexican Caribbean. No significant relationships were observed between turtles' migrating behavior and sea-surface temperature or geostrophic currents. Spatial analysis of the data recorded in this study has generated novel information on hawksbill turtle migratory patterns and feeding grounds, which will aid in decisionmaking for hawksbill turtle conservation in the Yucatan Peninsula.
\end{abstract}

KEY WORDS: Hawksbill turtle · Yucatan Peninsula $\cdot$ Migration · Post-nesting

\section{INTRODUCTION}

The hawksbill turtle Eretmochelys imbricata, like other sea turtles, has a complex life cycle that makes use of various terrestrial and marine habitats, including beaches, shallow coastal waters, coral reefs and oceanic waters. These turtles are also long-lived, taking decades to reach sexual maturity. Together, this spatial and temporal complexity exposes them to increasing anthropogenic threats on critical nesting, feeding, mating and resting habitats, rendering them highly vulnerable to extinction. Particularly as a result of unsustainable exploitation for food and tortoiseshell, this pan-tropical species is listed globally as critically endangered on the International Union for Conservation of Nature Red List (IUCN 2007) and legally protected by various international (Convention on International Trade in Endangered Species of Wild Flora and Fauna, Protocol of Specially Protected Areas and Wildlife of the Wider Caribbean Region, Inter-American Convention for the Protection and Conservation of Sea Turtles) and national legislation (e.g. Endangered Species Act in the USA, NOM-SEMARNAT-059-2001 in Mexico). 
After decades of commercial exploitation, Mexico enacted legal limits on hawksbill take in the 1970s and a complete ban on all sea turtle take in 1990. By the mid 1990s the hawksbill population that nests on the Yucatan Peninsula exhibited a dramatic increase to become the largest in the Atlantic Basin (Garduño et al. 1999, Meylan \& Donnelly 1999). This increase peaked in 1999 at more than 6000 nests but by 2004 the number started to decrease to less than $30 \%$ of this figure and the decline continues. A national review in 2005 prompted by the alarming trend identified 5 factors underlying hawksbill decline in the Yucatan Peninsula requiring urgent attention: bycatch in coastal waters, persistent knowledge gaps on the whereabouts and conservation status of feeding and breeding areas, possible impacts by seismic surveys for oil in the marine habitat, degradation and loss of nesting habitats, and use of inappropriate conservation measures on the nesting beaches (Abreu-Grobois et al. 2005).

Because of severe logistic and resource limitations, little is known about the marine habitats of sea turtle species present in Mexican waters. Hawksbill conservation efforts remain primarily focused on nesting beaches, despite the fact that nesting females spend on average less than $1 \%$ of their total lifetime in such habitats.

With the current hawksbill population crisis, a high priority has been placed on locating, characterizing and evaluating the condition of critical marine habitats. Only a few of prior investigations of this type have been carried out, notably those on hawksbill in the Yucatan Peninsula (Byles \& Swimmer 1994, Garduño et al. 2000a, Garduño et al. 2000b, Cuevas et al. 2007b). Researchers now recognize that it is necessary to focus efforts towards understanding which factors (natural and anthropogenic) influence hawksbill turtle life stages in the marine realm, and in what way. Such information will serve decision making and allow the development of a more integrative approach for hawksbill turtle conservation (i.e. protection and management).

The main goal of this study was to gain insight into the hawksbills' postnesting migratory behavior using satellite telemetry on 3 females breeding on the coast of Campeche, Mexico. Specifically we aimed at (1) identifying the location of their feeding ground(s), (2) determining the scope of their foraging home ranges, and (3) evaluating the influence of external physical factors (e.g. sea-surface temperature, geostrophic currents) on their migratory patterns. Such information is highly relevant for the identification of potential hazards at sea for hawksbill populations in this region.

\section{MATERIALS AND METHODS}

Study area. Hawksbill turtle populations nest along the entire western and northern coastline of the Yucatan Peninsula. We selected 3 of the major nesting sites in Campeche for our satellite transmitter applications: Isla del Carmen, Isla Aguada and Chenkan (Fig. 1). About $50 \%$ of the total yearly number of nests laid by hawksbills on the Campeche coast is concentrated on these 3 beaches (Cuevas et al. 2007a). The first 2 nesting beaches are contained in the Laguna de Terminos Flora and Fauna Protected Area, while Chenkan is located within this natural protected area's zone of influence.

Tracking. The 3 nesting females, nicknamed Jolbej (Isla del Carmen), Ka'ansaj (Chenkan) and Xinxinbaal (Isla Aguada), were encountered by night beach patrols and all were fitted with satellite tags in July 2006 after successful nestings. The females' sizes ranged between 83 (Ka'ansaj) and $96 \mathrm{~cm}$ (Jolbej) in curved carapace length (CCL), and each laid between 96 (Ka'ansaj) and 183 (Jolbel) eggs (Table 1). ST-20 model A1010 ARGOS platform transmitter terminals (PPTs; Telonics) were attached using a standard protocol (Balazs et al. 1996), with fiberglass and polyester

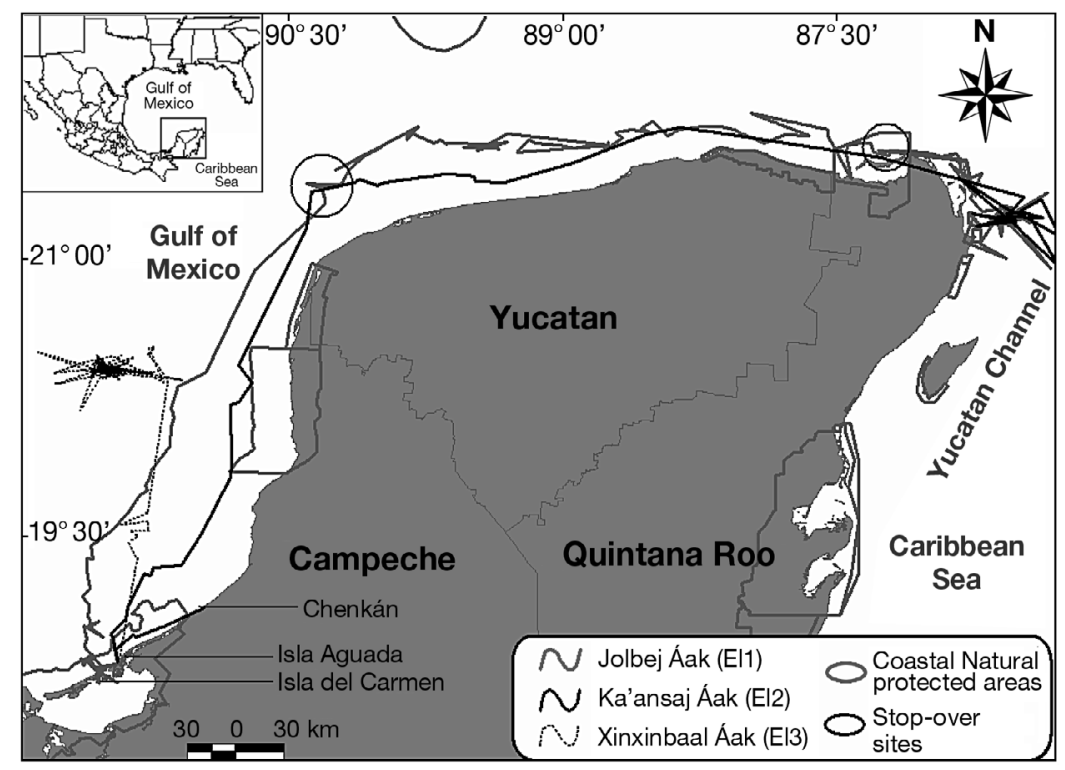

Fig. 1. Eretmochelys imbricata. Migratory movements of the 3 hawksbill turtles after nesting on the Campeche coast 
Table 1. Eretmochelys imbricata. Morphometric information for the 3 tracked post-nesting hawksbill females measured on their nesting beaches in Campeche state, Mexico. EI1: Jolbej; EI2: Ka'ansaj; EI3: Xinxinbaal

\begin{tabular}{|llcccl|}
\hline Turtle & Capture beach & $\begin{array}{l}\text { CCL } \\
(\mathrm{cm})\end{array}$ & $\begin{array}{l}\text { Laid } \\
\text { eggs }\end{array}$ & Metallic tags & $\begin{array}{l}\text { PTT deployment } \\
\text { date }\end{array}$ \\
\hline EI1 & Isla del Carmen & 96 & 183 & XQ789 / XQ798 & July 13, 2006 \\
EI2 & Chenkan & 83 & 96 & XQ639 / XQ635 & July 14, 2006 \\
EI3 & Isla Aguada & 92 & 107 & XQ672 / XQ610 & July 13, 2006 \\
\end{tabular}

resin. The PTT was placed on the highest point of the carapace, with the antenna pointing towards the animal's rear. The process lasted around $1.5 \mathrm{~h}$ for each turtle, during which time we recorded morphometric data and placed flipper tags (Inconel model 681 on each front flipper) prior to release.

We employed a $24 \mathrm{~h}$ ON programming mode, controlled by a saltwater switch, to turn the transmission off every time the turtle submerged. The PTT locations were estimated by the conventional ARGOS system using the polar-orbiting NOAA satellites. ARGOS location data were downloaded using the Satellite Tracking and Analysis Tool (STAT) (Coyne \& Godley 2005). The transmitters were equipped with a conventional temperature sensor and programmed to register mean dive time, as well as the number of dives during the $12 \mathrm{~h}$ prior to data transmission (dive $=$ any submergence lasting more than $10 \mathrm{~s}$ ). The location data were filtered to only include data from geographic location classes 3 , 2, 1, and A, as suggested by Hays et al. (2001a).

As stated by previous authors (Renaud \& Carpenter 1994, Hays et al. 2001a, Yasuda \& Arai 2005), the conventional satellite ARGOS location system generates important spatial biases on the location fixes that can be larger than $1 \mathrm{~km}$.

We obtained data on geostrophic currents and seasurface temperature (SST) using STAT, and compiled all of the spatial information in a geographic information system (GIS) using ArcView ver.3.2, to include both environmental and sea turtle location data. This procedure enabled us to further describe the migratory movements all the way from nesting to feeding grounds.

In order to evaluate differences in the turtles' bearings along different phases of their movements, we used ArcView to calculate their spatial orientation and only selecting data with location classes 3, 2, 1 or A. We used circular statistics to evaluate statistical differences between the turtles' headings along their migrating phases. We applied a modified Watson's $U^{2}$ test for testing angles and examined descriptive angle statistics, such as mean vector (a group of angle observations have a mean vector that can be calculated by combining each of the individual vectors; this has 2 properties: direction and concentration), concentration (the clumping level on 1 direction of the analyzed angle records), mean length (r) (the length will range from 0 to 1 ; larger $r$ values indicate that observations are clustered more closely around the mean than lower values), and the standard deviation (equivalent to its linear counterpart, but calculated from the length of the mean vector) (Zar 1999).

The ArcView GIS extension Animal Movement Analysis Extension (AMAE) ver. 2.0 (Hooge et al. 1999) was used to conduct spatial analyses of the location records. We assessed the females' site fidelity (a behavior that sea turtles normally exhibit; Carr 1980, Shaver et al. 2005) as a means to identify their internesting and feeding stages and thus estimate home ranges for these 2 habitats (Spencer et al 1990).

Home ranges were estimated using 2 methods. The Minimum Convex Polygon (MCP) method was used because of its simplicity of use and interpretation but, more importantly, because it enabled comparisons between our results and previous studies (Hooge et al. 1999). Nonetheless, being sensitive to sample size and biased by outliers, it typically overestimates home ranges. We also calculated home ranges using a non-parametric fixed Kernel probabilistic method for $50 \%$ and $95 \%$ polygons (Yasuda \& Arai 2005) with a specific smoothing factor $(\mathrm{H})$ value for each tracked female estimated ad hoc, which closely approaches to the least-squares cross-validation via using AMAE (values of 1359.82, 1255.95 and 1822.79 for Jolbej, Ka'ansaj and Xinxinbaal, respectively). We used the $50 \%$ polygon for our analyses, since it is the least influenced by outliers (Yasuda \& Arai 2005). The estimates were performed using location fixes in meters (Universal Transverse Mercator projection, WGS 1984 datum, for zones 15N and $16 \mathrm{~N}$ for Campeche Bank and Isla Mujeres, respectively).

To evaluate the influence of oceanographic variables on turtle migratory behavior, we used Spearman correlations. As suggested by Tröeng et al. (2005) and Broderick et al. (2007), we eliminated data that implied turtle speeds higher than $5 \mathrm{~km} \mathrm{~h}^{-1}$. We also employed an ArcView bearing extension to calculate sea turtle movement bearings along each female's trajectory; these data were then used together with oceanographic data to determine correlations with turtle migratory patterns.

Finally, in order to identify potential sources of anthropogenic threats (e.g. fisheries, oil survey sites), we compiled historic spatial and temporal information on the turtles' distribution in our study area. 


\section{RESULTS}

We tracked the 3 females for periods lasting between 167 and $510 \mathrm{~d}$. All headed northwards from the nesting beaches at the onset of their migration. Over the tracking period we received a total of 956 locations for Jolbej (EI1), 2938 locations for Ka'ansaj (EI2) and 1170 locations for Xinxinbaal (EI3). Because of location class filtering we were only able to use 19.5, 19.3 and 5.62\%, respectively, of the total locations obtained (Table 2).

\section{Characterization of migration routes}

Jolbej and Ka'ansaj migrated northwards towards coralline banks located on the northwestern tip of the Yucatan Peninsula, where they appeared to pause for approximately $4 \mathrm{~d}$. Both then skirted the Yucatan Peninsula coastline and continued towards the Caribbean Sea, never exceeding $60 \mathrm{~km}$ distance from the coast, and always remaining in areas shallower than $25 \mathrm{~m}$ depth (Fig. 1). Jolbej reached a zone near Isla Mujeres, Quintana Roo, where she settled. Ka'ansaj first paused for approximately $30 \mathrm{~d}$ in waters off Holbox Island before continuing onto an area near where Jolbej had settled, between Isla Mujeres and Isla Contoy, off the northeastern tip of the Yucatan. Both turtles traveled more than $500 \mathrm{~km}$ from their nesting beaches.

Ka'ansaj's migration was the longest, even though both she and Jolbej shared the same feeding area, and the latter performed more erratic movements while the former followed a more focused path to her feeding ground. This is because Ka'ansaj stayed for approximately $30 \mathrm{~d}$ at her stopover (Fig. 2, Table 3).

We found statistical differences in the bearings for the 2 phases in the migratory tracks (during migration and once established at the feeding grounds) for both Jolbej and Ka'ansaj (Fig. 3, Table 4).
Table 2. Eretmochelys imbricata. Frequency of location class (as defined by Hays et al. 2001a) records for the 3 tracked post-nesting hawksbill females around the Yucatan Peninsula, Mexico. Abbreviations as in Table 1

\begin{tabular}{|ccccccccc|}
\hline & \multicolumn{10}{c|}{ Location classes } & & & \\
\cline { 2 - 8 } & 3 & 2 & 1 & 0 & A & B & Z & $?$ \\
\hline EI1 & 3 & 15 & 28 & 28 & 137 & 334 & 18 & 393 \\
EI2 & 5 & 10 & 25 & 15 & 125 & 789 & 45 & 1923 \\
EI3 & 6 & 11 & 43 & 83 & 166 & 321 & 54 & 486 \\
\hline
\end{tabular}

The assessment of site fidelity showed that the location fixes during the inter-nesting periods for both females were random (Monte Carlo iterations $=1000$, linearity $=0.15$ and 0.84 for Jolbej and Ka'ansaj, respectively). In contrast, the location fixes once the turtles reached their feeding sites were significantly more spatially restricted than random movement patterns (Monte Carlo iterations $=1000$, linearity $=0.04$ and 0.11 for Jolbej and Ka'ansaj, respectively).

Inter-nesting movements were also analyzed. After transmitter deployment, Jolbej spent $17 \mathrm{~d}$ within $13 \mathrm{~km}$ of the coastline and laid her last nest of the season on the same beach (Isla del Carmen) where we initially

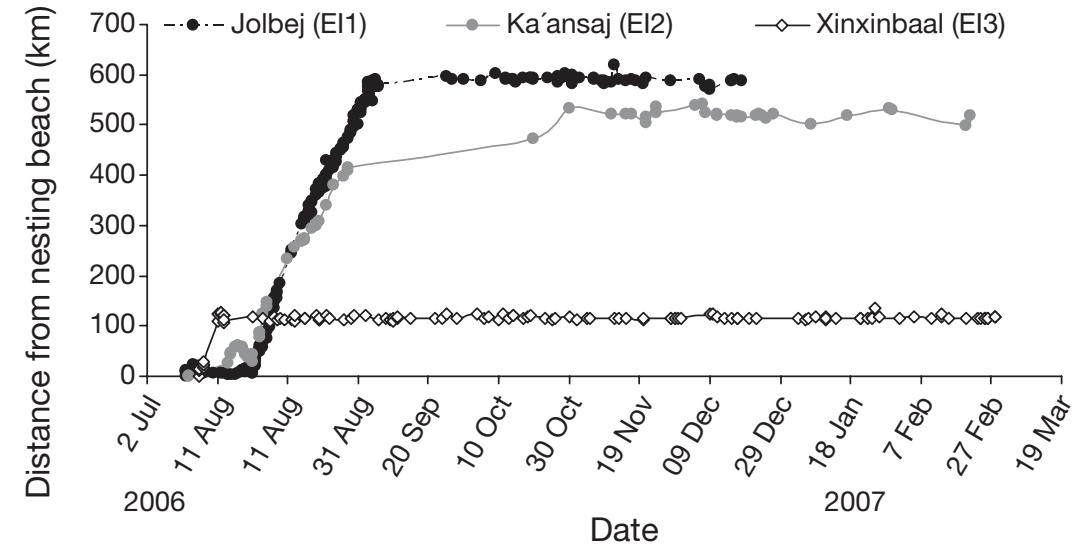

Fig. 2. Eretmochelys imbricata. Displacement plots indicating characteristic movement patterns: migration per se indicated by steep slope of the curve, arrival at foraging site by the asymptote. Slope of the curve is indicative of average speed during migration phase

Table 3. Eretmochelys imbricata. Summary of migration movements for the 3 tracked post-nesting hawksbill females. Abbreviations as in Table 1

\begin{tabular}{|lccccc|}
\hline Turtle & $\begin{array}{c}\text { Tag } \\
\text { duration } \\
\text { (d) }\end{array}$ & $\begin{array}{c}\text { Duration of migration } \\
\text { from nesting beach } \\
\text { to foraging site (d) }\end{array}$ & $\begin{array}{c}\text { Distance traveled from } \\
\text { nesting beach to } \\
\text { foraging site }(\mathrm{km})\end{array}$ & $\begin{array}{c}\text { Total distance } \\
\text { covered } \\
(\mathrm{km})\end{array}$ & $\begin{array}{c}\text { Foraging } \\
\text { destination }\end{array}$ \\
\hline EI1 & 167 & 55 & 595 & 1694 & Isla Mujeres \\
EI2 & 510 & 126 & 528 & 1238 & Isla Mujeres \\
EI3 & 446 & 11 & 116 & 1381 & Campeche Bank \\
\hline
\end{tabular}


encountered her (Fig. 4A). Ka'ansaj, on the other hand, spent $14 \mathrm{~d}$ within her inter-nesting range around Chenkan, after which she moved and nested at a different site $60 \mathrm{~km}$ southwest (Isla Aguada, Fig. 4B).

The home range analysis using the Kernel probabilistic method indicated that Jolbej had $50 \%$ feeding

\section{Migrating period}
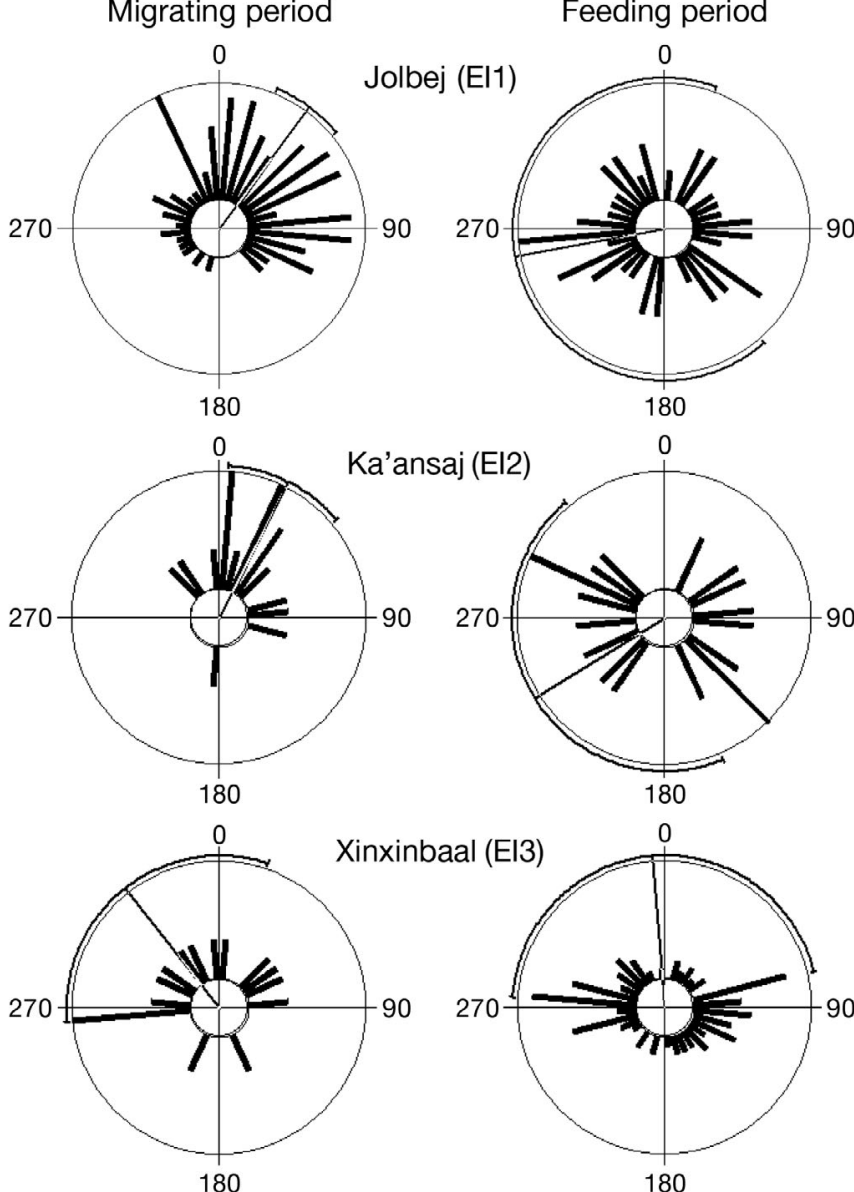

180

Fig. 3. Eretmochelys imbricata. Circular histograms for tracking data from 3 post-nesting hawksbill females during the 2 different phases, migrating and feeding. Solid line arches represent circular SD home range core area and MCP estimates double the size of those of Ka'ansaj (Fig. 5A,B, Table 5).

We estimated the inter-nesting home range for Jolbej and Ka'ansaj even though the assumption of site fidelity was not statistically fulfilled. We proceeded because of the management value of such information on the geographic scope of the species during the nesting season. We only estimated the MCP home range in order to minimize the error of such spatial estimations. Ka'ansaj used a larger inter-nesting area compared to Jolbej.

Once the turtles had arrived at their feeding grounds, it took them on average $50 \pm 13$ d (mean \pm $\mathrm{SD})$ to reach $100 \%$ of their total occupied feeding home range (Fig. 6). Ka'ansaj took the longest to reach her final feeding ground after deployment (126 d), and it took her $38 \mathrm{~d}$ to settle on her final feeding home range area $(\mathrm{MCP})$, located just east of Isla Mujeres. Her core home range area was slightly larger than $10 \mathrm{~km}^{2}$. For Jolbej, it took $55 \mathrm{~d}$ to reach her final core feeding home range area, an area larger than $23 \mathrm{~km}^{2}$.

For Ka'ansaj's swimming speed and heading we did not find any significant influence of SST $(\mathrm{p}>0.05, \mathrm{~N}=$ $22, r=0.029)$, current direction $(p>0.05, r=0.07, N=$ 22 ) or current speed ( $p>0.05, r=0.45, N=12$ ). On the other hand, for Jolbej we did find a statistically significant relationship between SST and swimming speed, although the power of the correlation was low ( $p<0.05 ; N=160, r=0.23$ ). We found no significant correlations with current direction $(\mathrm{p}>0.05, \mathrm{r}=0.1$, $\mathrm{N}=90$ ) or current speed ( $\mathrm{p}>0.05, \mathrm{r}=0.1, \mathrm{~N}=69$ ) with Jolbej.

We found no spatially explicit evidence of current or recent anthropogenic impacts at the northeastern end of the Yucatan Peninsula (i.e. Mexican Caribbean) where we located Jolbej's and Ka'ansaj's home ranges.

Xinxinbaal was the only female that, immediately after transmitter attachment, initiated her migration away from the breeding areas and remained within the limits of the Bank of Campeche. She exhibited the shortest traveled distance to her feeding ground

Table 4. Eretmochelys imbricata. Summary of circular statistics for the 3 tracked post-nesting hawksbill females at 2 different stages of their trip (migration per se and once at their feeding grounds). Abbreviations as in Table $1 .{ }^{* *}$ Results statistically significant between stages $(\mathrm{p}<0.05)$

\begin{tabular}{|c|c|c|c|c|c|c|c|}
\hline Turtle & Stage & $\begin{array}{l}\text { Mean } \\
\text { vector }\end{array}$ & $\begin{array}{l}\text { Length of } \\
\text { mean }(r)\end{array}$ & Median & Concentration & $\begin{array}{c}\text { Circular } \\
\text { SD }\end{array}$ & $\begin{array}{c}\text { Number of } \\
\text { observations }\end{array}$ \\
\hline \multirow[t]{2}{*}{ EI1 ** } & Migrating & $36.21^{\circ}$ & 0.516 & $36.227^{\circ}$ & 1.2 & $65.904^{\circ}$ & 104 \\
\hline & Feeding & $259.443^{\circ}$ & 0.094 & $246.516^{\circ}$ & 0.189 & $124.615^{\circ}$ & 49 \\
\hline \multirow[t]{2}{*}{ EI2 $* *$} & Migrating & $26.507^{\circ}$ & 0.698 & $26.008^{\circ}$ & 1.992 & $48.626^{\circ}$ & 17 \\
\hline & Feeding & $238.404^{\circ}$ & 0.045 & $298.077^{\circ}$ & 0.091 & $142.488^{\circ}$ & 18 \\
\hline \multirow[t]{2}{*}{ EI3 } & Migrating & $321.632^{\circ}$ & 0.339 & $304.789^{\circ}$ & 0.721 & $84.267^{\circ}$ & 16 \\
\hline & Feeding & $355.101^{\circ}$ & 0.014 & $34.654^{\circ}$ & 0.027 & $167.777^{\circ}$ & 98 \\
\hline
\end{tabular}



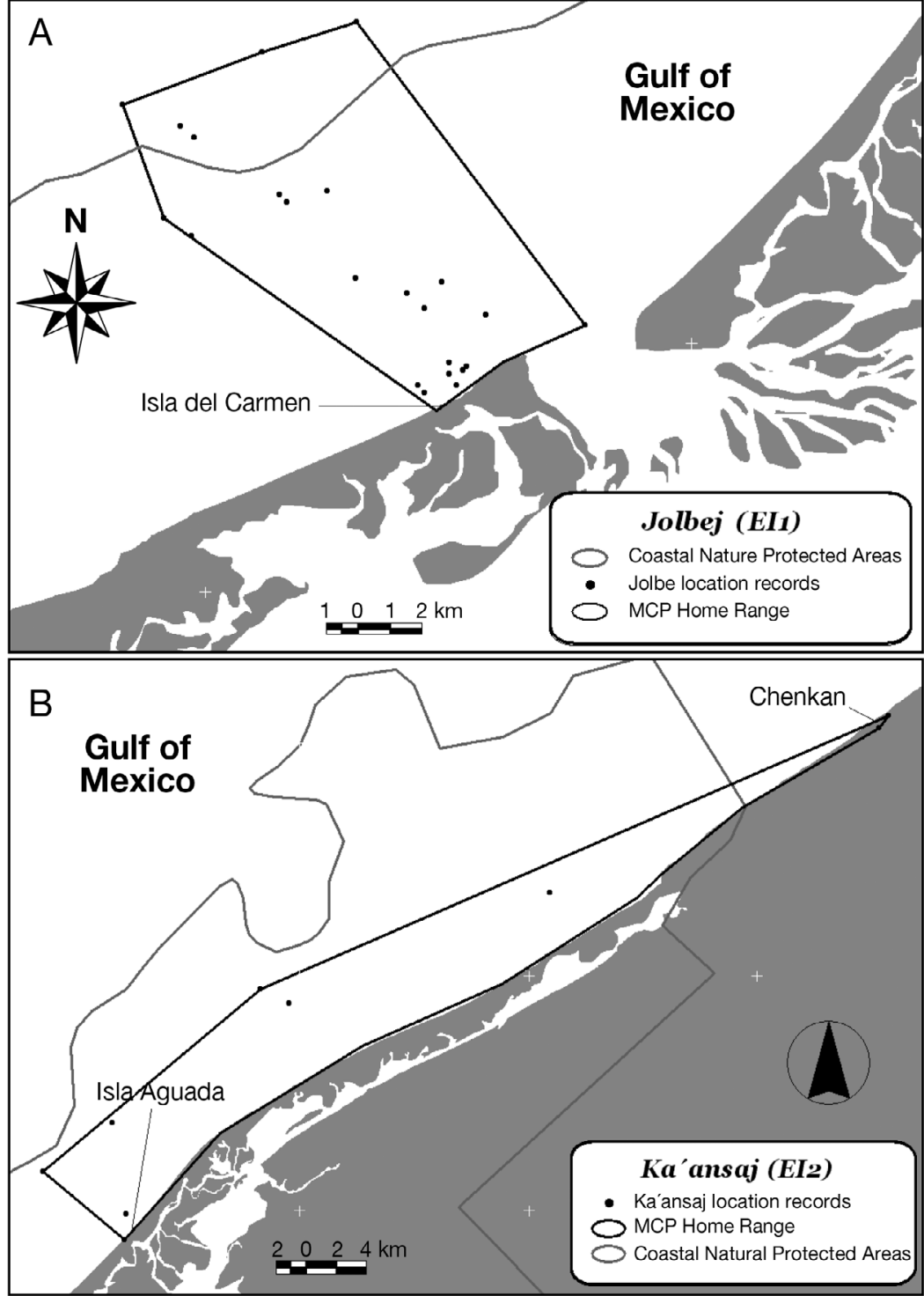

Fig. 4. Eretmochelys imbricata. (A) Jolbej's (EI1) and (B) Ka'ansaj's (EI2) internesting movements and home range polygons determined using Minimum Convex Polygons (MCP). Projection: Universal Tranverse Mecator, Datum WGS 1984, zones N16N

(116 $\mathrm{km}$ off the northern coast of Campeche), reaching it just $11 \mathrm{~d}$ after leaving the nesting beach (Fig. 2, Table 3). She showed no significant differences in her fixed bearing throughout the migration (Fig. 3, Table 4). Nonetheless, similar to the other 2 females, Xinxinbaal exhibited a slightly smaller circular SD, higher concentration and greater mean length (r) during the migrating stage compared to the feeding stage.

The site fidelity analysis for Xinxinbaal showed that the movements at her feeding site were more restricted than random movement patterns (Monte
Carlo iterations $=1000, r=0.03$ ). Xinxinbaal exhibited the greatest feeding ground home range (50\% polygon), followed by Jolbej (Fig. 5C, Table 5 ). It took Xinxinbaal around $60 \mathrm{~d}$ to establish her total feeding home range area, with a core home range area exceeding $26 \mathrm{~km}^{2}$ (Fig. 6).

We found no significant relationships between SST $(\mathrm{p}>0.05, \mathrm{~N}=83, \mathrm{r}=$ $0.21)$, current direction $(\mathrm{p}>0.05, \mathrm{r}=$ $0.1, \mathrm{~N}=90)$ and speed $(\mathrm{p}>0.05, \mathrm{~N}=69)$ with Xinxinbaal's swimming speed and heading.

\section{DISCUSSION}

The total length of the achieved tracking period is believed to be adequate to confidently cover the complete return trip of post-nesting females to their feeding grounds. While some researchers have expressed concern that having only a small number of useful location records is inadequate for accurate spatial and statistical analyses (Horrocks et al. 2001, Hays et al. 2001a), the collected data for this work are adequate to rebuild the migratory trip of the post-nesting females to their feeding grounds.

\section{Migratory patterns}

Previous studies that have measured migratory movements for post-nesting hawksbill turtles have reported short travel distances from nesting beaches to feeding grounds (Meylan 1999) with a notable exception in van Dam et al. (2007). For instance, Byles \& Swimmer (1994) found that both of 2 post-nesting hawksbill females deployed with transmitters in Campeche remained within the limits of the Campeche Bank. In our study only 1 of the 3 females stayed in this area after nesting, while the other 2 migrated to Mexican Caribbean waters (Fig. 1).

Even though significant contrasts in migratory behavior of hawksbill females in different regions make comparisons difficult, scarcity on migratory information in the Mexican region forced us to take advantage of the best available information for the species, even though it comes from different regions. 

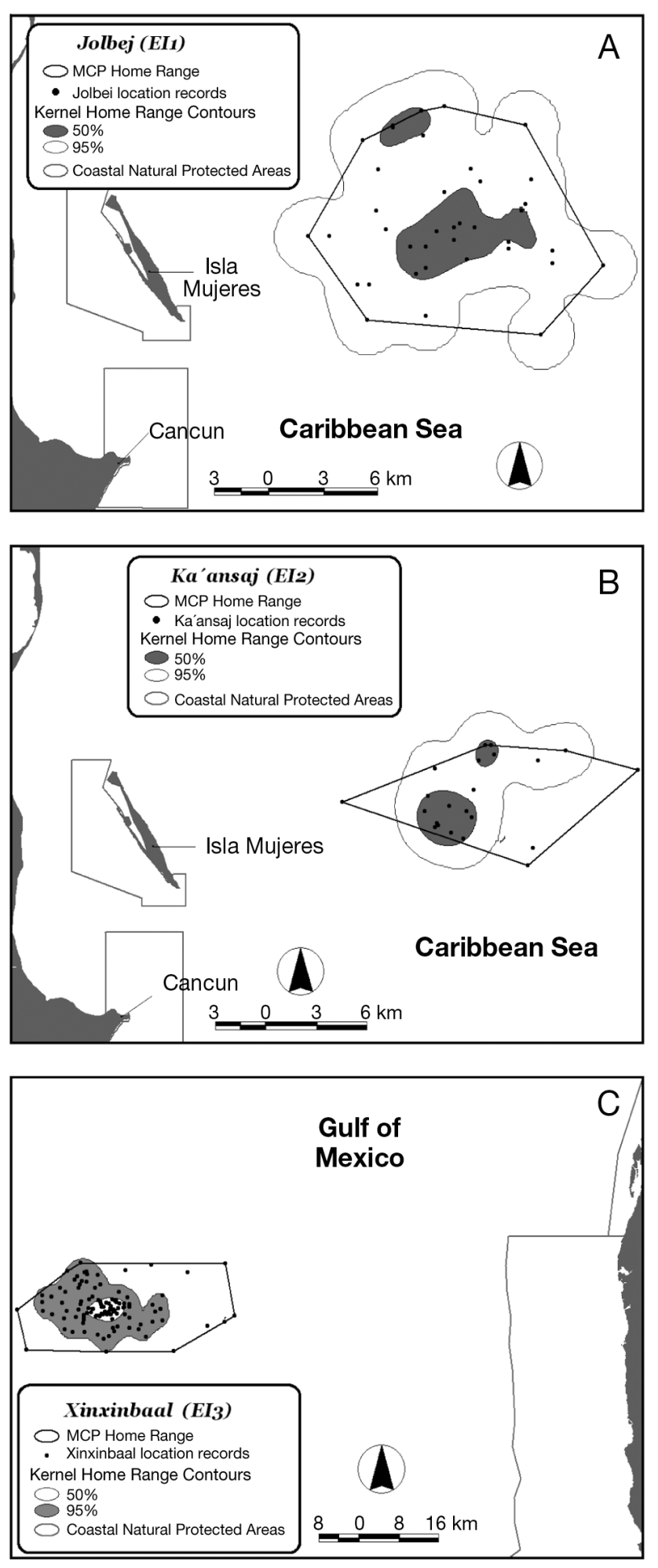

Fig. 5. Eretmochelys imbricata. Estimates for home ranges at foraging sites for (A) Jolbej and (B) Ka'ansaj at their common feeding ground in the Mexican Caribbean, and (C) for Xinxinbaal off the west coast of Campeche inside the Gulf of Mexico. Projection: Universal Tranverse Mecator, Datum WGS 1984, zones N16N (A \& B) and 15N (C)
Table 5. Eretmochelys imbricata. Home range statistics for the 3 tracked turtles at 2 different migration stages (internesting and feeding) at the Yucatan Peninsula, Mexico. Abbreviations as in Table 1

\begin{tabular}{|llrrrr|}
\hline \multirow{2}{*}{ Turtle } & Migratory & \multicolumn{3}{c|}{ Area $\left(\mathrm{km}^{2}\right)$} & MCP area \\
& stage & $50 \%$ & $70 \%$ & $95 \%$ & $\left(\mathrm{~km}^{2}\right)$ \\
\hline EI1 & Inter-nesting & & & & 87.56 \\
& Feeding & 23.93 & 69.46 & 190.62 & 138.66 \\
EI2 & Inter-nesting & & & & 282.09 \\
& Feeding & 10.42 & 23.65 & 90.11 & 415.62 \\
EI3 & Feeding & 26.70 & 51.47 & 278.58 & 618.32 \\
\hline
\end{tabular}

Balazs et al. (1996) found that maximum post-nesting travel distances for 5 Hawaiin hawksbill turtles did not exceed $315 \mathrm{~km}$, much less than the longest distance registered in this study $(595 \mathrm{~km})$. Nonetheless, both our and Balazs et al.'s (1996) trackings indicated that throughout the migratory trajectories, turtles remained a short distance from the coast. Likewise, a study by Tröeng et al. (2005) reported migration trajectories very close to the coast for 2 post-nesting hawksbill females from Tortuguero, Costa Rica-neither one of which traveled more than $450 \mathrm{~km}$ from nesting beach to feeding ground. Mortimer \& Balazs (1999) found that 5 post-nesting hawksbill females did not travel more than $175 \mathrm{~km}$ from their nesting beach. The only exception to shortdistance migrations (about $2000 \mathrm{~km}$ ), van Dam et al. (2007) nonetheless found trajectories that remained close to the coastline.

In our study, the 2 females with foraging destinations in the Caribbean exhibited stopovers, a behavior that has been suggested to prove that migrating females do feed along their migratory periods (Broderick et al. 2007). Such stopovers were determined based on the restricted movements of the females in a relatively small area for more than $3 d_{\text {; }}$ this behavior was considered here as a signal of the female stopping in a specific area along her migratory trip.

In what we consider an outstanding finding, both Jolbej and Ka'ansaj, tagged at 2 different nesting beaches on different nights, migrated to the same feeding site in the Mexican Caribbean. Based on bathymetric data, this area appears to be close to an underwater drop off, which constitutes a submarine habitat type previously reported as a typical hawksbill habitat (van Dam \& Diez 1996a). This result suggests the need to gather more spatial and ecological information to substantiate the value for preserving this sea turtle feeding area and thus improving survival for hawksbills in Mexico.

The migratory behavior described in this paper fulfill the type $\mathrm{A} 1$ and $\mathrm{A} 3$ migratory patterns described by Godley et al. (2007), referring to hawksbill females 


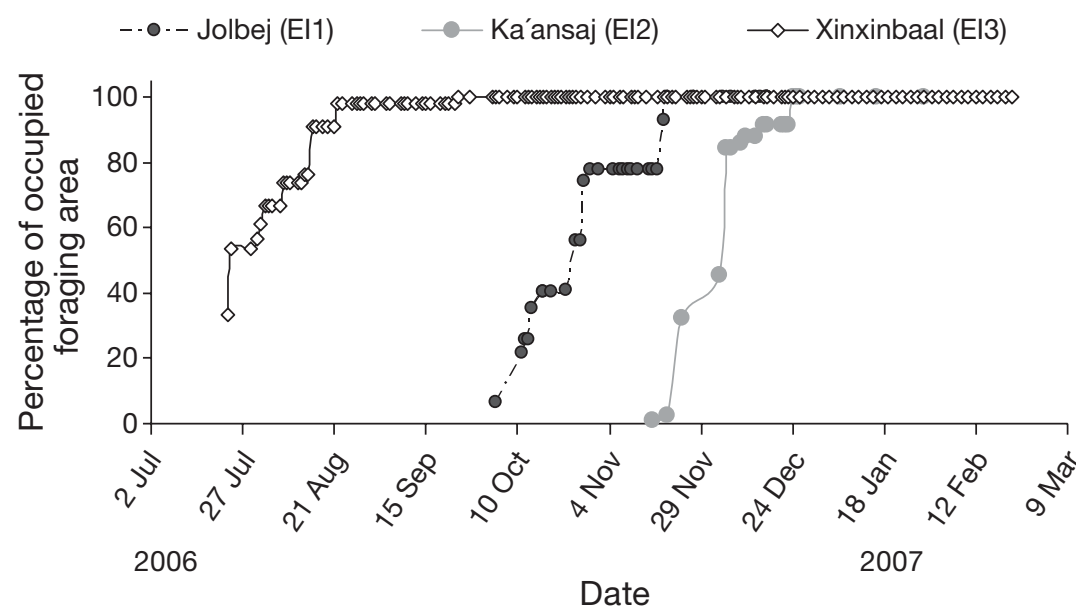

Fig. 6. Eretmochelys imbricata. Incremental MCP foraging home range area plots for the 3 satellite-tracked post-nesting hawksbill turtles off the Yucatan Peninsula, Mexico
Jolbej and Ka'ansaj were consistent with those reported using other methods for nesting hawksbills in the Yucatan Peninsula (Cuevas et al. 2006, González-Garza 2007). The large difference in the size of the estimated inter-nesting $\mathrm{MCP}$ and $50 \%$ kernel polygon home ranges for the 2 females was due to Ka'ansaj moving to a different nesting beach to lay a subsequent clutch. Starbird et al. (2001) reported inter-nesting movements, detected by radio telemetry (which can be more accurate than satellite telemetry) no further than $2.5 \mathrm{~km}$ from the coast of the U.S. Virgin Islands, contrasting with the $13 \mathrm{~km}$ reported here for continental nesting beaches.

On the other hand, once at their feeding grounds the turtles also showed dif-

nesting in continental beaches and moving along the coastal shelf to discrete foraging areas (Jolbej and Ka'ansaj), and individuals staying in neritic areas in the vicinity of the nesting beach, migrating only short distances (Xinxinbaal), respectively.

The turtle navigation here reported and the significant differences between the migratory and foraging stages differs from a pattern expected as merely random movements, indicating that the studied hawksbills described a well-defined directional trend towards a fixed point (Moorcroft \& Lewis 2006). Such specific movement patterns might aid in predicting the migratory stage at which a given turtle is located any given moment, that is, if it has already arrived at its feeding grounds or is still traveling.

The limited accuracy of satellite telemetry data (Hays et al. 2001a, Yasuda \& Arai 2005) has been cited as an issue for avoiding its use for estimating fine-scale analyses and decision-making (Renaud \& Carpenter 1994, Hays et al. 2001a). However, given the urgent need for spatial, ecological and behavioral information for hawksbill turtles in our region in light of their current critical condition (Godley et al. 2007) and the financial restrictions on aquiring GPS location transmitters, we feel it is justified to derive a first approximation using the available information so as to define and focus conservation planning strategies for critical habitats. In spite of the importance of identifying the spatial scope of the inter-nesting phase due to heavy interactions with near-shore human activities, to our knowledge only 1 previous study has analyzed this aspect for hawksbills (Starbird et al. 2001). During this period, at least in Campeche, these females appear to stay close to the shoreline, no further than $13 \mathrm{~km}$ offshore. Further, the inter-nesting periods recorded for ferences in their estimated MCP and 50\% kernel home range areas, with Jolbej having the smallest feeding home range and Xinxinbaal the largest. Such differences in the quality of food items at the 2 areas (Gulf of Mexico and Caribbean). If so, one would expect to find higher-quality food at Caribbean habitats, with turtles there requiring a smaller foraging area to satisfy their nutritional needs, in contrast to the Gulf of Mexico (see Broderick et al. 2007).

In both cases, the estimated feeding ground range was larger than the inter-nesting range. The estimated MCP foraging home ranges in this study ranged from 88 to $618 \mathrm{~km}^{2}$. In comparison, Renaud \& Carpenter (1994) reported home ranges from 954 to $4279 \mathrm{~km}^{2}$ for loggerhead turtles Caretta caretta in the northern portion of the Gulf of Mexico. The MCP home ranges reported here are much smaller and this may be explained by differences in the feeding requirements of different species, as well as the food-item availability at feeding grounds (van Dam \& Diez 1996b, León \& Bjorndal 2002).

When turtles arrived at their feeding grounds, the occupied area rapidly increased until reaching an asymptote, at which point the turtles progressively restricted their movements to small, specific areas. Such a spatio-temporal pattern, initially referred to as 'the simplest home range mechanistic model' or more recently as the 'localizing tendency model' (Moorcroft \& Lewis 2006), has been described for different life stages of hawksbill turtles (van Dam \& Diez 1996a,b, Mortimer \& Balazs 1999, Houghton et al. 2003, Tröeng et al. 2005). Now that foraging sites have been located, future studies can be applied to characterize the foraging ecology of adult hawksbills. These are necessary to ences in feeding home range might suggest differ- 
gain urgently needed insight into possible effects on breeding activity of changes in foraging quality due to environmental fluctuations.

\section{Physical and anthropogenic factors affecting hawksbill migratory behavior}

As expected with fully-grown animals, swimming behavior did not change as a function of current direction or current magnitude in the region, even with strong currents in the Yucatan channel facing Caribbean-bound turtles. As Hays et al. (2001b) found in green turtles, we found that SST had no effect on swimming behavior, even though we found a weak positive correlation between swimming speed and SST for 1 female (Jolbej). Furthermore, neither current magnitude nor current heading inside the Gulf of Mexico showed any significant influence on turtle swimming behavior. This confirms that adult females are not influenced by dominant oceanic currents (ZavalaHidalgo et al. 2003), as they are large and strong enough to move in any direction, regardless of current magnitude and/or heading. This is in agreement with Luschi et al. (2003), who concluded that currents will have a significant effect on sea turtle movement only when they cross open-sea stretches heading towards a specific target. The latter was not the case in this study, as the 3 tracked females remained relatively close to shoreline, always within the limits of the continental shelf of the Yucatan Peninsula.

Xinxinbaal's foraging site was the only one from this study for which information on fishing activities is available. The trawling fleet that exploited this area ceased operating in 2005 and as a result, this area is no longer exploited with such harmful fishing gear (Páramo-Romero 2006). There are currently no detailed reports on the spatial distribution of fishing efforts by minor fleets in the region and the discovery of a feeding site here highlights an urgent need for information on small-scale fishing activities in the Yucatan Peninsula's continental shelf, especially as it has been shown that the fishing practices with some of the gear used by some of these minor fleets can affect sea turtles (Hays et al. 2003).

The impact of seismic surveys from oil explorations on sea turtles has not been well-studied. The few studies available have demonstrated the enactment of a general alarm response and a subsequent avoidance by sea turtles in response to air-gun shots, and in some cases temporal or permanent hearing loss (Moein et al. 1995, McCauley et al. 2000, U.S. Minerals Management Service 2004, Moreira de Gurjao et al. 2005).

Based on these studies, it is clear that the use of air guns represents an important anthropogenic factor potentially affecting sea turtles in the region and its impacts on hawksbill individuals and populations remains to be tested. This is especially true given that the sites where such explorations have been conducted spatially coincide with feeding grounds or migratory trajectories reported for adult hawksbills (i.e. results from this study McCauley et al. 2000).

To summarize, the present study is one of the few that has tracked hawksbill turtles in the Yucatan Peninsula, and has shown that post-nesting females (1) exhibit directional and well-defined migration trajectories towards specific feeding grounds that remain located within Mexican territorial waters, and (2) remain close to the coastline. The tracked females showed non-random movements during their migration period and exhibited a limited home range feeding area. Oceanographic features such as SST and superficial geostrophic currents had no evident influence swimming patterns and thus, the migratory behavior of the targeted hawksbills. Finally, as patterns of hawksbill migratory behavior found overlap with some human activities, such as fisheries and seismic surveys, further studies are needed to evaluate the true impact these activities have on hawksbill individuals and populations in the region.

Acknowledgements. Financial support from CONACYT and the Campeche State Government through project CAMP2005-C01-046 is gratefully acknowledged. This work would not have been possible without the participation of field biologists at the nesting beaches where we attached the transmitters in Isla del Carmen, Isla Aguada and Chenkán. Special thanks to B. González and P. García for their great help and enthusiasm.

\section{LITERATURE CITED}

Abreu-Grobois FA, Guzmán-Hernández V, Cuevas E, AlbaGamio M (2005) Memorias de la reunión de especialistas 'Rumbo a la COP 3: Diagnóstico del estado de la tortuga carey (Eretmochelys imbricata) en la Península de Yucatán y determinación de acciones estratégicas'. CONANP, Mexico

Balazs GH, Miya RK, Beavers SC (1996) Procedures to attach a satellite transmitter to the carapace of an adult green turtle, Chelonia mydas. In: Keinath JA, Barnard D E, Musick JA, Bell BA (eds) Proc 15th Annu Symp Sea Turtle Biol Conserv NMFS-SEFSC-387, p 21-26

Broderick AC, Coyne MS, Fuller WJ, Glen F, Godley BJ (2007) Fidelity and overwintering of sea turtles. Proc R Soc B Biol 274:1533-1538

Byles RA, Swimmer YB (1994) Post-nesting migration of Eretmochelys imbricata from the Yucatan Peninsula. In: Bjorndal KA, Bolten AB, Jonson DA, Eleazar PJ (eds) Proc 14th Annu Symp Sea Turtle Biol Conserv NMFS-SEFSC351, p 202

Carr A (1980) Some problems of sea turtle ecology. Am Zool $3: 489-498$ 
Coyne MS, Godley BJ (2005) Satellite Tracking and Analysis Tool (STAT): an integrated system for archiving, analyzing and mapping animal tracking data. Mar Ecol Prog Ser 301:1-7

Cuevas E, Guzmán-Hernández V, García-Alvarado P, AbreuGrobois FA, Tzeec-Tuz M, González-Garza BI (2006) Fifteen years of hawksbill tagging data in the Yucatan Peninsula, Mexico. Tech Rep Natl Fish Wildl Found \#2005-0008-013

Cuevas E, Guzmán-Hernández V, González-Garza B, GarcíaAlvarado PA and others (2007a) Reunión preliminar para la diagnosis de la tortuga Carey en el Golfo de México y Mar Caribe. Pronatura Península de Yucatán-USFWS

Cuevas E, Liceaga-Correa MA, Garduño-Andrade M (2007b) Spatial characterization of a foraging area for immature hawksbill turtles (Eretmochelys imbricata) in Yucatan, Mexico. Amphib-reptilia 28:337-346

Garduño M, Guzmán V, Miranda E, Briceño-Dueñas R Abreu-Grobois FA (1999) Increases in hawksbill turtle (Eretmochelys imbricata) nestings in the Yucatán Peninsula, Mexico, 1977-1996: Data in support of successful conservation? Chelonian Conserv Biol 3:286-295

Garduño M, Márquez R, Schroeder B, Balazs G (2000a) Migración y buceo de la tortuga Carey en la Península de Yucatán. In: Memorias del X Taller y I Congreso Regional sobre Programas de Conservación de Tortugas Marinas en la Península de Yucatán

Garduño M, Maldonado A, Lope R (2000b) Dinámica poblacional de la tortuga de carey (Eretmochelys imbricata) en su área de forrajeo, Río Lagartos, Yucatán. CONABIO, Mexico City (FB500/L269/97)

- Godley BJ, Bluementhal JM, Boderick AC, Coyne, MS, Godfre $\mathrm{MH}$, Hawkes LA, Witt MJ (2007) Satellite tracking of sea turtles: Where have we been and where do we go next? Endang Species Res 4:3-22

González-Garza BI (2007) Aspectos reproductivos de la tortuga carey (Eretmochelys imbricata, LINNAEUS 1766) en Isla Holbox, Quintana Roo, México: 1990-2005. Senior Dissertation, Autonomous University of Nuevo Leon, Mexico

$>$ Hays GC, Akesson S, Godley BJ, Luschi P, Santidrian P (2001a) The implications of location accuracy for the interpretation of satellite tracking data. Anim Behav 61: $1035-1040$

Hays GC, Dray M, Quaife T, Smyth TJ and others (2001b) Movements on migrating Green turtles in relation to AVHRR derived sea surface temperature. Int $\mathrm{J}$ Remote Sens 22(8):1403-1411

Hays GC, Broderick AC, Godley BJ, Luschi P, Nichols WJ (2003) Satellite telemetry suggests high level of fishinginduced mortality in marine turtles. Mar Ecol Prog Ser 262:305-309

Hooge PH, Eichenlaub WM, Solomon EK (1999) Using GIS to analyze animal movements in the marine environment. United States Geological Survey, Alaska Biological Science Center, Anchorage, AK

Horrocks JA, Vermeer LA, Krueger B, Coyne M, Schroeder BA, Balazs GH (2001) Migration routes and destination characteristics of post-nesting hawksbill turtles satellitetracked from Barbados, West Indies. Chelonian Conserv Biol 4:107-114

Houghton JDR, Callow MJ, Hays GC (2003) Habitat utilization by juvenile hawksbill turtles (Eretmochelys imbricata) around a shallow water coral reef. J Nat Hist 37: $1269-1280$

IUCN (2007) 2007 IUCN Red List status assessment hawksbill turtle (Eretmochelys imbricata). Mortimer JA, Donnelly M (assessors) Marine Turtle Specialist Group. www.iucnmtsg.org/red_list/ei/

León YM, Bjorndal KA (2002) Selective feeding in the hawksbill turtle, an important predator in coral reef ecosystems. Mar Ecol Prog Ser 245:249-258

Luschi P, Hays GC, Papi F (2003) A review of long-distance movements by marine turtles, and the possible role of ocean currents. Oikos 103:293-302

McCauley RD, Fewtrell J, Duncan AJ, Jenner C and others (2000) Murdoch Jand McCabe K (2000) Marine seismic surveys- A study of environmental implications. APPEA J 2000:692-708

Meylan A (1999) International movements of immature and adult Hawksbill turtles (Eretmochelys imbricata) in the Caribbean Region. Chelonian Conserv Biol 2:189-194

Meylan AB, Donnelly M (1999) Status justification for listing the hawksbill turtle (Eretmochelys imbricata) as Critically Endangered on the 1996 IUCN Red List of the Threatened Animals. Chelonian Conserv Biol 2:200-224

Moein SE, Musick JA, Keinath JA, Barnard DE, Lenhardt ML, George R (1995) Evaluation of seismic sources for repelling sea turtles from hopper dredges. In: Hales LZ (ed) Sea Turtle Research Program: Summary Report. Technical Report CERC-95, p 90-93

Moorcroft PR, Lewis MA (2006) Mechanistic home range analysis. Princeton University Press, Princeton, NJ

Moreira-de-Gurjao L, Pereira-de-Freitas JE, Silva-Araújo D (2005) Observations of marine turtles during seismic surveys off Bahia, Northeastern Brazil. Mar Turtle Newsl 108:8-9

Mortimer JA, Balazs GH (1999). Post-nesting migrations of hawksbill turtles in the granitic Seychelles and implications for conservation. In: Kalb H, Wibbels $\mathrm{T}$ (eds) Proc 19th Ann Symp Sea Turtle Biol Conserv. NMFS-SEFSC443, p 22-25

Páramo-Romero I (2006) Asignación del esfuerzo pesquero, a dos escalas espaciales, en la pesquería de arrastre de escama en el Banco de Campeche. MSc thesis, Unidad Merida, Yucatan

Renaud ML, Carpenter JA (1994) Movements and submergence patterns of loggerhead turtles (Caretta caretta) in the Gulf of Mexico determined through satellite telemetry. Bull Mar Sci 1:1-15

Shaver DJ, Schroeder BA, Byles RA, Burchfield PM, Peña J, Márquez R, Martínez HJ (2005) Movements and home ranges of adult male Kemp's Ridley sea turtles (Lepidochelys kempii) in the Gulf of Mexico investigated by satellite telemetry. Chelonian Conserv Biol 4: 817-827

Spencer SR, Cameron GN, Swihart RK (1990) Operationally defining home range: temporal dependence exhibited by hispid cotton rats. Ecology 71:1817-1822

Starbird CH, Hillis-Starr Z, Harvey JT, Eckert SA (2001) Internesting movements and behavior of hawksbill turtles (Eretmochelys imbricata) around Buck Island Reef National Monument, St. Croix, U.S. Virgin Islands. Chelonian Conserv Biol 3:237-243

Tröeng S, Dutton PH, Evans D (2005) Migration of Hawksbill turtles Eretmochelys imbricata from Tortuguero, Costa Rica. Ecography 28:394-402

U.S. Minerals Management Service (2004) Geological and geophysical exploration for mineral resources on the Gulf of Mexico outer continental shelf. U.S. Department of the Interior, Gulf of Mexico OCS Region. OCS EIA/EA MMS 2004-054

> van Dam RP, Diez CE (1996a) Diving behavior of immature hawksbills (Eretmochelys imbricata) in a Caribbean cliffwall habitat. Mar Biol 127:171-178 
van Dam RP, Diez CE (1996b) Predation by hawksbill turtles on sponges at Mona Island, Puerto Rico. In: Lessios HA, Macintyre IG (eds) Proc 8th Int Coral Reef Symp 2: 1421-1426

van Dam RP, Diez CE, Balazs GH, Colón Colón LA, McMillan WO, Schroeder B (2007) Sex-specific migration patterns of hawksbill turtles breeding at Mona Island, Puerto Rico. Endang Species Res 4:85-94

Editorial responsibility: Jeffrey Seminoff,

La Jolla, California, USA
Yasuda T, Arai N (2005) Fine-scale tracking of marine turtles using GPS-Argos PTTs. Zool Sci 22:547-553

Zar JH (1999) Biostatiztical analysis. 4th edn. Prentice-Hall, New York

Zavala-Hidalgo J, Morey SL, O'Brien JJ (2003) Seasonal circulation on the western shelf of the Gulf of Mexico using a high-resolution numerical model. J Geophys Res 108:1-19

Submitted: January 29, 2008; Accepted: August 3, 2008 Proofs received from author(s): October 15, 2008 